\title{
Japan's Yen Loan, Prerequisite to Mass FDI from Japan
}

\author{
Kikuo Oishi ${ }^{1}$ \\ ${ }^{1}$ Independent Researcher, member of the Japan Society for International Development, Japan \\ Correspondence: Kikuo Oishi, Independent Researcher, member of the Japan Society for International Development, \\ Japan.
}

Received: May 15, 2017

Accepted: June 1, 2017

Online Published: June 12, 2017

doi:10.5430/ijfr.v8n3p40

URL: https://doi.org/10.5430/ijfr.v8n3p40

\begin{abstract}
Japan initiated the TICAD process in 1993. In 2016, it was held for the $6^{\text {th }}$ time in Kenya, where Japan promised to invest USD 30 billion in the African continent by 2019. Examining the relationship between ODA and FDI from Japan for the case of Asia, it was clear that Japanese ODA results in a "vanguard effect" on FDI; yen loan, one of the types of ODA, helped the recipient Asian countries to attract three times larger FDI than the total amount of yen loans. In order to attract increased FDI from Japan, African countries need to win yen loans from Japan if wishing to get more Japanese FDI. Although Japan's tied aid projects can facilitate Japanese companies' expansion to the recipient countries, it is crucial for them to take into account the OECD-DAC rules. Specifically, upper middle income countries are not eligible for tied loans. Also it is beneficial to keep in mind Japan's priorities for yen loan such as Global Environmental Problems and Climate Change, Health/Medical Care and Services, Disaster Prevention and Reduction and Human Resource Development. In addition, Japan's new national effort to export high quality infrastructure (for example, by the Japan Overseas Infrastructure Investment Corporation for Transport and Urban Development (JOIN)) can benefit African countries that urgently need to upgrade urban infrastructure.
\end{abstract}

Keywords: foreign direct investment, official development aid, yen loan, vanguard effect, Africa, TICAD

\section{Introduction}

The first Tokyo International Conference on African Development (TICAD) was held in 1993. The conference continues to be held every 5 years by the Japanese government as a platform to discuss development assistance efforts in the African continent, and the most recent TICAD VI was held in Nairobi Kenya in 2016. The first four conferences of TICAD had a heavier emphasis on ODA; and in the $6^{\text {th }}$ Conference the emphasis on trade and private investment in Africa was strengthened. This more recent trend is evident as two thirds of the pledged amounts of money flows from Japan to Africa are through foreign direct investment (FDI) projects. In his opening address of TICAD VI, Prime Minister Abe pledged 30 billion USD of investments to Africa during the period between August 2016 and 2019. Of this pledge, USD 10 billion in the form of ODA and USD 20 billion from the private sector with emphases on infrastructure, human resource development, and public health (MOFA, 2016).

\subsection{What Do African Countries Need in Order to Attract Japanese FDI?}

The total amount of FDI from Japan shows an increasing trend during the last two decades, minus a temporary decline due to the Leman Shock while the home economy was suffering from the economic slump so called "lost decades," characterized by sluggish economic growth and deflation. The total amount of Japanese FDI reached USD 130 billion in 2008, and once dropped to USD 57 billion in 2010. Subsequently, it recovered to USD 136 billion in 2014 (JETRO, 2017). The changes in this FDI trend were affected by currency exchange rates, where Japanese yen showed historical strength against other currencies including US dollar and euro (USD 1 was worth less than JPY 100 from 2009 to 2013, which benefited Japanese FDI flows).

During the recent period between 2006 and 2015, the main destinations of Japan's FDI were Asia, North America, and Europe. The stock of FDI to Africa at the end of 2015 was about USD 10.26 billion; however, this amount is dwarfed when compared to the FDI flows of USD 358.95 billion to Asia for the same period. This indicates that even with the emphasis on African relations through TICAD conferences held by the Japan government, private investment in Africa is yet to be sufficiently promoted. According to JETRO (2016), Japanese FDI Stock at the end of 2015 by region were (in USD billion) 358.95 for Asia; 435.14 for North America; 70.95 for Latin America; 74.16 for Oceania; 30246 for Europe; 7.12 for Middle East; and 10.26 for Africa. 
Table 1 summarizes sector-wise FDI from Japan to Africa, and shows how the amount of FDI from Japan to Africa varied among sectors. The net FDI from Japan reveals as negative for some years, caused chiefly by withdrawals in Finance and Insurance sub-sector. The manufacturing sector has been positive in general except for 2010. An increase of FDI in the manufacturing sector is welcomed because host countries aim to create employment opportunities through FDI, and the contributions from the development of the manufacturing sector to job creation is deemed significant. The question for African countries is how they can attract more investment from Japan, especially for the manufacturing sector.

Table 1. Japanese FDI into/out of Africa by sector from 2009 to 2013 (in JPY 10 billion)

\begin{tabular}{|c|c|c|c|c|c|}
\hline year & 2009 & 2010 & 2011 & 2012 & 2013 \\
\hline Manufacturing & 182.3 & -0.7 & 255.7 & 179 & 135 \\
\hline Lumber and Pulp & & & 2.8 & 4 & 16 \\
\hline Chemicals and pharmaceuticals & & & 199.9 & & \\
\hline Rubber and leather & & & & & 94 \\
\hline Iron, non-ferrous, and metals & 126.7 & 4.9 & -12.0 & 11 & -27 \\
\hline Transportation equipment & 38.3 & & 58.2 & 169 & -4 \\
\hline Non-manufacturing & -440.2 & -315.5 & 121.9 & -89 & -639 \\
\hline Mining & -252.4 & & 4.6 & 2 & 1 \\
\hline Transportation equipment & 75.5 & 125.1 & 330.9 & 119 & -311 \\
\hline Wholesale and retail & 29.0 & 45.5 & 93.1 & 50 & 61 \\
\hline Finance and insurance & -427.4 & -558.2 & -378.3 & -345 & -522 \\
\hline Services & & & 6.0 & 5 & 8 \\
\hline Total & -258.0 & -316.2 & 377.6 & 90 & -504 \\
\hline
\end{tabular}

* Sub-sectors of manufacturing with zero FDI are food, textile, petroleum, glass and ceramics, general machinery, electric machinery, and precision machinery. Sub-sectors of non-manufacturing sectors zero FDI were Farming and forestry, Fishery and marine products, Construction, Communications, and Real estate.

Source: Bank of Japan, 2016

\subsection{Contributions; Relevance to African Countries}

Through TICAD I - V, promotion of trade and investment in Africa was a major topic. One of the major channels of Japan's interaction with African countries has been through ODA, and yen loans are one of the major modalities of ODA. In TICAD V, the Japanese government emphasized that FDI is beneficial in terms of creation of business opportunities for local enterprises, and for employment opportunities in addition to technology transfers. The challenge persists, however, in how to attract and increase private investment in various sectors including infrastructure, agriculture, manufacturing, and tourism.

Affirming that the private sector is a vital engine of growth, Japan strives to support Africa in strengthening the private sector, promoting greater private investment, improving the investment climate, and bolstering the legal and regulatory frameworks. Japan aims to encourage and expand trade, tourism and technology transfer, and assist the development of the SMEs in Africa. Japan also supports regional integration to expand intra-regional trade and create new opportunities for private sector development and employment in Africa.

As aforementioned, the most recent TICAD VI held in August 2016 in Nairobi, Kenya resulted in the Nairobi Declaration, which states: "we recognize the increasingly significant role of business in facilitating the continent's development, particularly in promoting fair trade and investments, supporting entrepreneurial development, promoting technology transfer and creating decent jobs." In order to achieve such a socio-economic transition, Prime Minister Abe promised to bring USD 30 billion from Japan to Africa as investments; a pledged financial support that consists of USD 10 billion worth ODA and USD 20 billion as private FDI before the end of 2019. 
The pledge given by Japan in TICAD VI to realize USA 20 billion of private FDI sounded encouraging and promising to African countries, but also challenging considering that Japanese FDI seems following capital inflow by Official Development Assistance. Especially, it seems that there is a correlation between yen loan flow and FDI. If the increased capital inflow through yen loans is a prerequisite to an increase in private FDI from Japan, those countries that wish to attract more Japanese FDI need to win more yen loan projects first.

It is very common that private investment is inspired by public investment, and it is easy to suppose that FDI is not an exception. Figure 1 shows the correlation plotted for the case of Thailand from 1969 to 1998; the amount of FDI of given years was plotted on the amount of yen loan (Ministry of Foreign Affairs and JETRO).

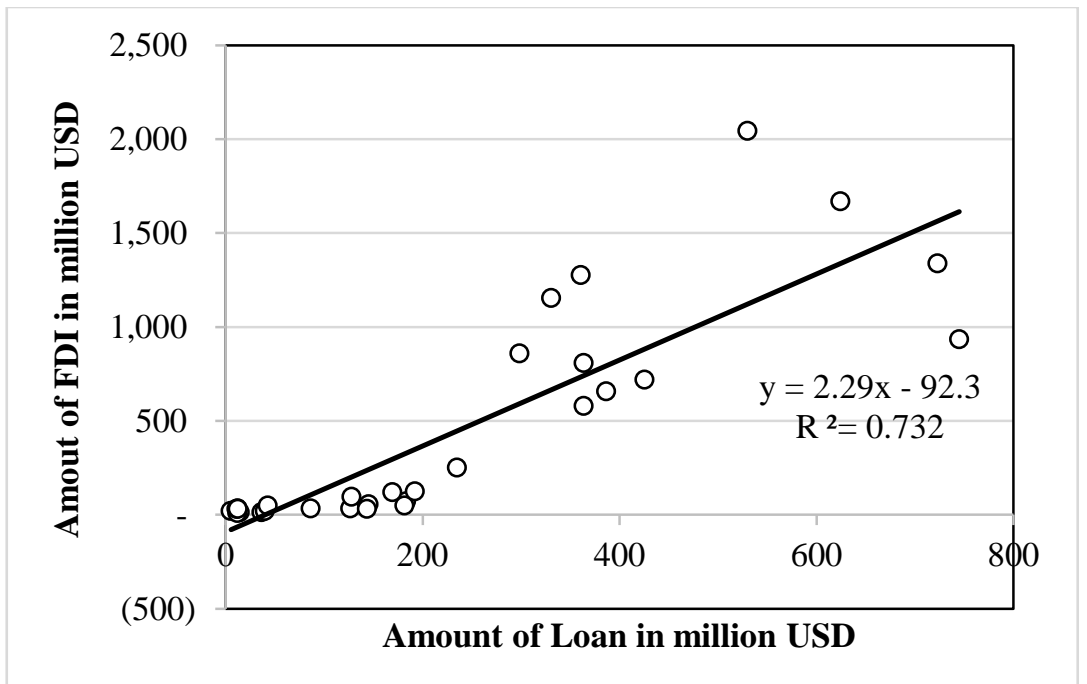

Figure 1. The relationship between yen loan and Japanese FDI in Thailand

Source: Author created using the data from MOFA and JETRO

Such a tendency is natural because services and goods of ODA are provided by Japanese companies, especially in the case of tied loan supported projects. For tied loans, it is beneficial for service and goods providers to open local offices due to various reasons such as tax benefit and subsidies from the host countries, which can result in further full-fledged investment. Considering these effects, this paper examines the relationship between yen loan and FDI, and subsequently, will argue that African countries can make use of the pledges made during TICAD VI by opting for more yen loan supported projects in order to attract FDI from Japan.

\section{Literature Review}

\subsection{Determinants of FDI}

There are a large number of studies on determinants of FDI using quantitative or statistical and econometrical approaches; many of them list macroeconomic features explaining attractive investment environments.

Chen (2009) examines the investment activities of multinational firms throughout the world and find that: "improved market accessibility within an integrated region leads to an increase in outside multinationals' activities. Countries that are integrated with larger markets experience a greater increase in FDI; those with a large labor endowment attract more multinationals especially in labor-intensive industries, whereas capital-abundant countries experience a decline in FDI. Regional economic integration also leads to rise of export-platform FDI. Countries with preferential access to large export markets are particularly more likely to become the platforms from which multinationals export to third countries."

As a specific case to Asia, Hattai and Rajan (2008) examine the intra-regional FDI flows in Asia and found macroeconomic determinants of FDI such as "Intra-regional FDI activity between emerging Asian economies is driven by economic factors such as market sizes (especially in the host country), export intensity, real exchange rate changes (measuring wealth effects), measures of financial depth in the host country, institutional factors (such as low political risk in host country and shared legal origin) and an operational FTA." Cevis and Camurdan (2007) also 
show the importance of macroeconomic factors to FDI that "the previous period FDI which is directly related to the host countries' economic resources is important as an economic determinant." They also argue that the general economic performance of host country such as the inflation rate, the interest rate, the growth rate, and the trade (openness) rate affected the level of FDI inflow. Blonigen and Piger (2011) apply the Bayesian statistical techniques in search of the determinants of FDI and conclude that the significant factors of FDI are real GDP of both countries and physical distance between two countries, parent-country per capita GDP, relative labor endowments, and regional trade agreements.

Developed economies have assisted less developed ones, especially those in severely disadvantaged ones in improving their economic performance through various measures with official development assistance, or ODA, as one of the most common approaches, and loan is a major form of ODA. However the abovementioned studies do not discuss the direct effect of ODA on FDI although it is not difficult for one to imagine the causal relationship between them because many ODA projects are implemented in order to improve recipient countries' economic conditions.

\subsection{ODA as a Determinant of FDI}

A number of studies have been carried out to determine the relationship between ODA and FDI, and previous literature reveals both negative and positive effects of ODA on FDI. One of the notable works is Harms and Lutz (2006) in which they address questions between the two polarities of ODA paving the road for FDI or ODA suffocating private FDI by diverting resources towards unproductive activities. Analyzing panel data from various developing and emerging economies in the 1990s, they point out that the marginal effect of aid on FDI is nearly zero, controlling for the country's institutional environment. However, they also show a positive effect for countries in which private agents face a substantial regulatory burden.

On the contrary, Selaya and Sunesen (2008) find strong evidence that ODA invested in complementary inputs, such as public infrastructure and human capital, draws in foreign capital; while ODA invested in physical capital, such as machinery and factory, crowds out FDI. Nevertheless, the overall effect of these two types of ODA was positive, but small.

Rahim et al. (2014) study this issue specific to Asia, and analyze data from 14 East and South Asian countries for the period between 1995 and 2012 using the Feasible Generalized Least Square estimation method (FGLS), and found that that the effect of ODA on FDI was significantly positive. In addition, their results suggested that FDI is significantly affected by corruption control, rate of return, infrastructure, human capital, market potential, and political stability. Their study also indicates that East Asia enjoys a locational advantage in attracting FDI in relation to South Asia.

For the case of Japan, Blaise (2009) researches the relationship between Japanese ODA and FDI for the period from 1980 to 2007 in ASEAN 4 countries, namely, Indonesia, Malaysia, Philippines, and Thailand. Using conditional logit analysis, he shows that Japanese ODA flows did have a positive impact on the location choices of private investors. This study also suggests that other factors such as agglomeration effects, the quality of infrastructure, which are considered as crucial factors for profit-maximization for private investors, and shows a greater effect on companies' location choice than ODA.

Kimura and Todo (2009) examine the relationship between ODA and FDI from the top five countries, namely, France, Germany, Japan, the United Kingdom, and the United States, during the period from 1990 to 2000. They summarize the effects of ODA on FDI and list five types: negative "rent-seeking effect;" "Dutch-disease effect;" positive "infrastructure effect;" "financing effect;" and "vanguard effect." The vanguard effect means that a donor country's ODA paves a road to FDI from the same country, but does not necessarily attract FDI from other countries. Their results show no vanguard effect for France, Germany, UK and US, but a robust vanguard effect in the Japanese case - meaning that Japanese ODA promotes FDI from Japan. They conclude that $6 \%$ of Japanese FDI was attributable to ODA.

Government intervention might not seem appropriate from the laissez-faire point of view, but for the case of Japanese companies, such a government intervention is desired according to the Japan External Trade Organization (JETRO). JETRO annually conducts the "Survey on Business Conditions of Japanese Companies in Africa," and in 2015 they targeted 354 Japanese-affiliated companies in Africa. Among the surveyed, 196 companies responded to the question about the Japanese government's market intervention and $75 \%$ of them wished for the strengthening of the support from the Japanese government. In particular, frequently listed requests were "lobbying the African governments for various requests and concerns from business side" (58.7\%); "funding (investment loans, trade and investment insurance, standby credit)" (46.4\%); and "signing bilateral treaties such as FTAs/EPAs, tax treaties, 
investment protection agreements, etc." (42.9\%). Moreover, a half of the companies surveyed regarded "quality of employees (including technical capability)" as problematic, especially in Portuguese-speaking countries (JETRO, 2015). As a result, the Japanese government has responded to such needs by strengthening the capacity to provide funding needs.

These existing studies indicate the significance of government intervention to the FDI decision making of Japanese companies. A closer examination of the vanguard effect for the Japanese cases can help African countries to find out what to do in order to attract investment from Japan.

\section{Analysis on Japanese Yen Loan and FDI (Note 1)}

\subsection{Growing Number of Japanese Companies Outside of Japan}

After the World War II, Japanese economy saw a rapid growing phase and the total number of Japanese companies expanding abroad exceeded 1,000 during the 1970s, but did not show dramatic increase until the 2000s as depicted in Figure 2. One of the explanations for the sluggish increase in the number of expanding Japanese companies was that they did not have the necessity to seek opportunities in overseas markets during Japan's rapid economic growth called "bubble" from the 1980s to the 90s. Figure 2 shows an acceleration of Japanese companies' expansion to overseas markets between 2001 and 2005, especially among "small" companies.

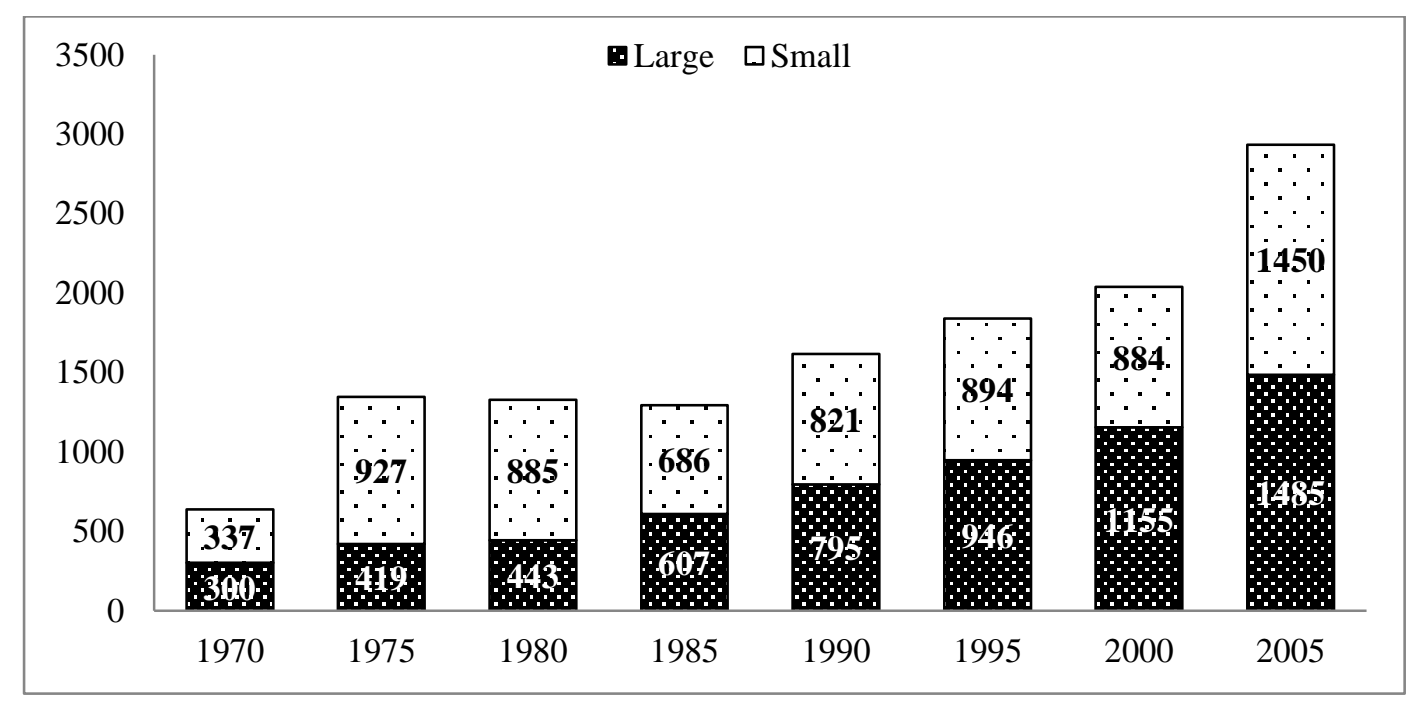

Figure 2. Change in the number of Japanese companies that have establishments overseas

*the division of size is based on asset; a "large" company holds greater than JPY 100 million in assets and "small" holds equal to JPY 100 million and less.

Source: The Medium and Small Business Research Institute, 2011

At a global level, there was a strong relationship between the total amount of Japanese official loans and the number of Japanese companies expanding abroad. Figure 3 shows the relationship between loans issued by the Japanese government to other countries and the numbers of Japanese companies that expanded to overseas markets from 1971 to 2005. Note that the missing numbers of companies between observation years (every 5 years) were estimated using period-specific growth rates (the growth rate for each 5 year period) from the observed numbers of companies shown in Figure 2. Excel® estimated 0.77 as the correlation efficiency between two variables. 


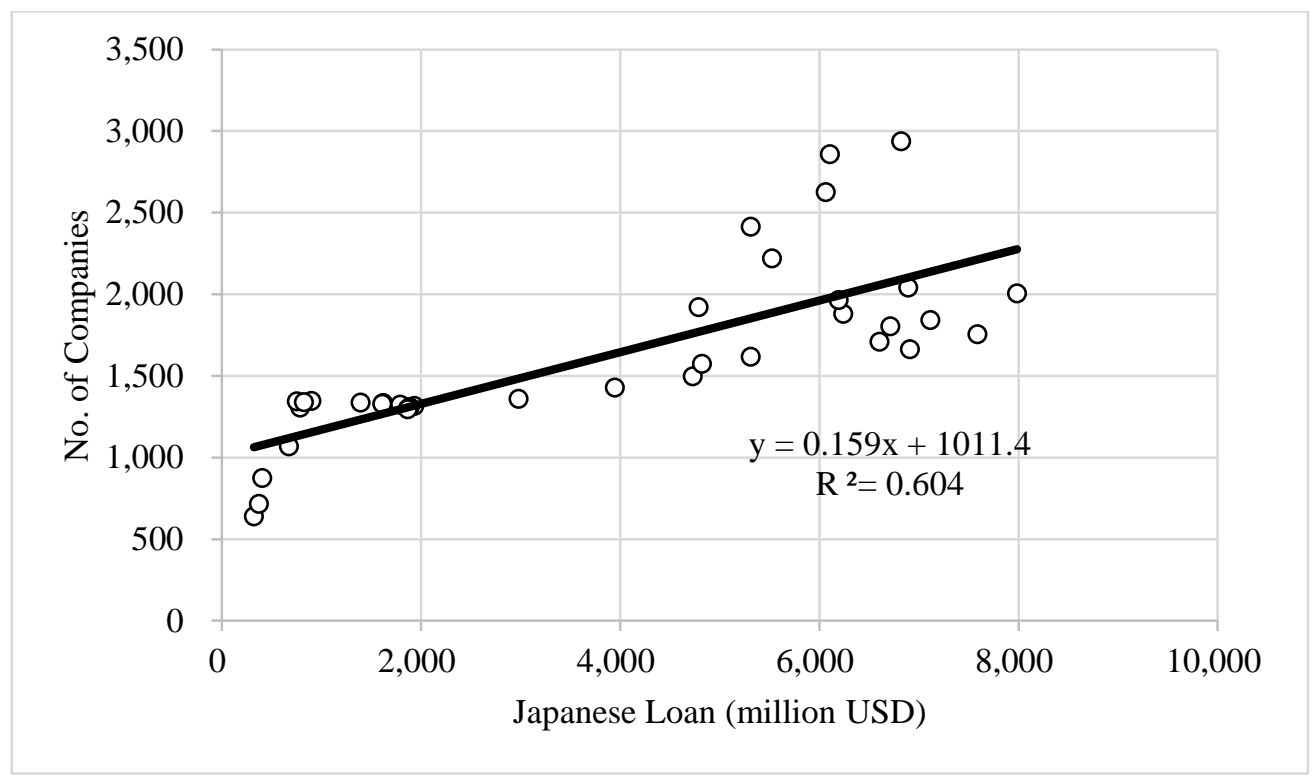

Figure 3. Relationship between Japan's loan and number of Japanese companies going abroad (1971 - 2010) Source: created by author from MOFA and JETRO

\subsection{Evidence of Strong Relationship between Yen Loans and FDI from Japan}

The majority of Japanese owned overseas companies have been established in Asia because it is common among them to look at Asia first as the priority market for FDI. According to MOFA, in 2015 the number of overseas companies (and proportion) owned by Japanese were: 49983 (70.3\%) for Asia; 8689 (12.2\%) for North America; $5773(8.1 \%)$ for West Europe; 1458 (2.0\%) for East Europe and former Soviet Union countries; 1378 (1.9\%) for Central America; $1315(1.8 \%)$ for Oceania; $1130(1.6 \%)$ for South America; $756(1.1 \%)$ for Middle East; and 687 $(1.0 \%)$ for Africa.

Figure 4 depicts the linear relationship between yen loans from Japan and FDI to other Asian countries for the period from 1970 to 2004. According to the regression coefficient for yen loans on FDI, yen loans increased 1.57 times the amount of FDI in Asia.

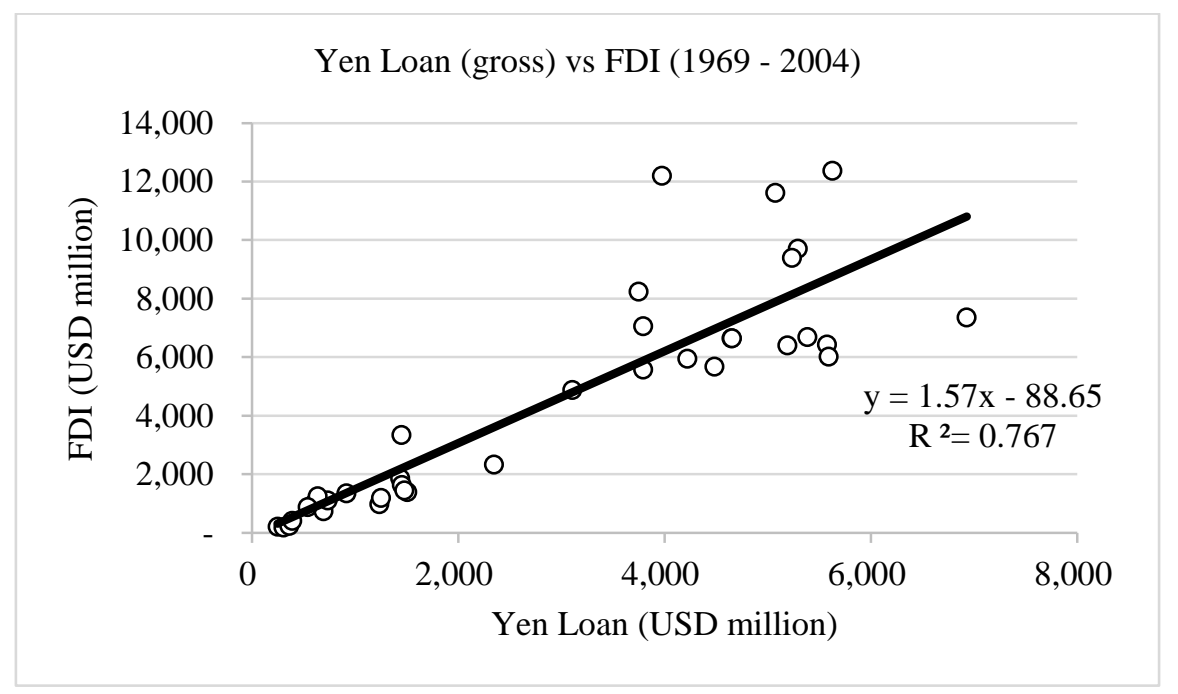

Figure 4. Relationship between Japanese yen loans and FDI in Asia from 1970 to 2004

Source: created by author from MOFA and JETRO 
Using a mathematical expression to show the relationship between the amount of FDI for a given year $(F D I(t+1))$ and the amounts of yen loans $(\operatorname{Loan}(t))$, FDI $(F D I(t))$ in previous year, and other factors, can be written as follows.

$$
F D I(t+1)=f(\operatorname{Loan}(t), F D I(t), \text { other factors })
$$

The second-degree Taylor polynomial approximation gives the following equation.

$$
F D I(t+1)=\alpha_{0}+\alpha_{1} F D I(t)+\alpha_{2} \operatorname{Loan}(t)+\alpha_{3}[F D I(t)]^{2}+\alpha_{4}[\operatorname{Loan}(t)]^{2}+\alpha_{5}[\operatorname{Loan}(t)] *[F D I(t)]+e(t)
$$

where $\alpha$ denotes coefficients and $e(t)$ is the error term. This approximation assumes that there is interaction effect between yen loans and FDI.

The obtained coefficients and regression statistics using Excel® are shown in Table 2. Note that the effects of other factors are not given, but can be obtained as error terms.

\begin{tabular}{|c|c|c|c|c|c|c|}
\hline & Coefficients & Standard Error & t Statistic & $P$-value & \multicolumn{2}{|c|}{ Regression Statistics } \\
\hline$\alpha_{0}$ & -401.18689 & 479.76624 & -0.83621 & 0.41011 & Multiple R & 0.967 \\
\hline$\alpha_{1}$ & -0.77959 & 0.50456 & -1.54508 & 0.13355 & $\mathrm{R}^{2}$ & 0.935 \\
\hline$\alpha_{2}$ & 3.04609 & 0.86723 & 3.51242 & 0.00153 & Adjusted $\mathrm{R}^{2}$ & 0.923 \\
\hline$\alpha_{3}$ & -0.00011 & 0.00004 & -2.56370 & 0.01601 & Standard Error & 1023.22 \\
\hline$\alpha_{4}$ & -0.00079 & 0.00014 & -5.68537 & 0.00000 & Observations & 34 \\
\hline$\alpha_{5}$ & 0.00070 & 0.00014 & 5.01082 & 0.00003 & & \\
\hline
\end{tabular}

Table 2. Coefficients and regression statistics

This result implies that taking the first order derivative, with respect to yen loans, gives the marginal effect of yen loans to $F D I(t+1)$ from Japan in USD million.

$$
\frac{d[F D I(t+1)]}{d \operatorname{Loan}(t)}=3.05-0.00079 * 2 * \operatorname{Loan}(t)+0.00070 * F D I(t)
$$

For example, suppose that in previous year, the flow of FDI was USD 100 million and there is a yen loan of USD 10 million for this year. In this case, there is still a marginal positive effect of this particular yen loan on FDI, which results in attracting USD 3.105 million of FDI if there was an additional USD 1 million of yen loan.

The marginal effect of yen loans on FDI from Japan becomes negative when the amount of yen loan surpasses USD 2033 million $+0.47^{*} F D I(t)$. For example, if $F D I(t)$ was USD 7000 million, a total yen loan greater than USD 5323 million could not yield a positive effect on FDI. This supports the finding in Cevis \& Camurdan (2007) that the existence of previous FDI had a positive effect on FDI in the subsequent year.

\subsection{Japanese FDI on the Rise}

\subsubsection{Stagnating Economy and Expansion of Japanese Companies}

The Japanese economy has been stagnant since the 1990s after the miraculous growth from the 1960s. The post-bubble state of the Japanese economy has been characterized with undesirable features such as deflation, declining real wage, and sluggish growth. The predicted significant population decline is expected to further slowdown economic growth. Japan has yet to find an effective solution for this downturn, which may be another reason for the capital flight from Japan to other countries, especially, to emerging countries (e.g., MUFJ Research Consulting, 2016). In the early 2000s until the Leman Shock in 2009, Japan's FDI steadily increased. After the shock, the level of Japanese FDI recovered within 5 years with a slight decline in 2015.

This capital flight is an unwelcome phenomenon to the Japanese economy and one of the causes of further economic stagnation. The Cabinet Office of the Japanese government listed the causes of the accelerated capital flight as contracting domestic market and expanding emerging economy markets; technological advancement in emerging economies; strong yen after the Leman Shock; damage to production facility due to major earthquakes; increases in energy prices; and impacts of the Free Trade Agreement (FTA) in other countries such as South Korea (Cabinet Office, 2016a). As a result, the Japanese government has been implementing various measures to promote domestic investment. The Cabinet Office explains that current Japanese FDI aspires to create local demand and gain markets within emerging economies, unlike production and reimport oriented FDI in the 1990s. 
Kimura \& Todo (2010) show that the Japanese FDI is guided by the "vanguard effect" of the Japanese ODA. Thus, the following section examines how the Japanese ODA, especially yen loans, has been implemented in the recent years.

Figure 5 depicts how Japanese ODA has favored heavily on Asia. The total amount of ODA spending has been almost always been greater than 50\% and visibly consistent throughout the long period.

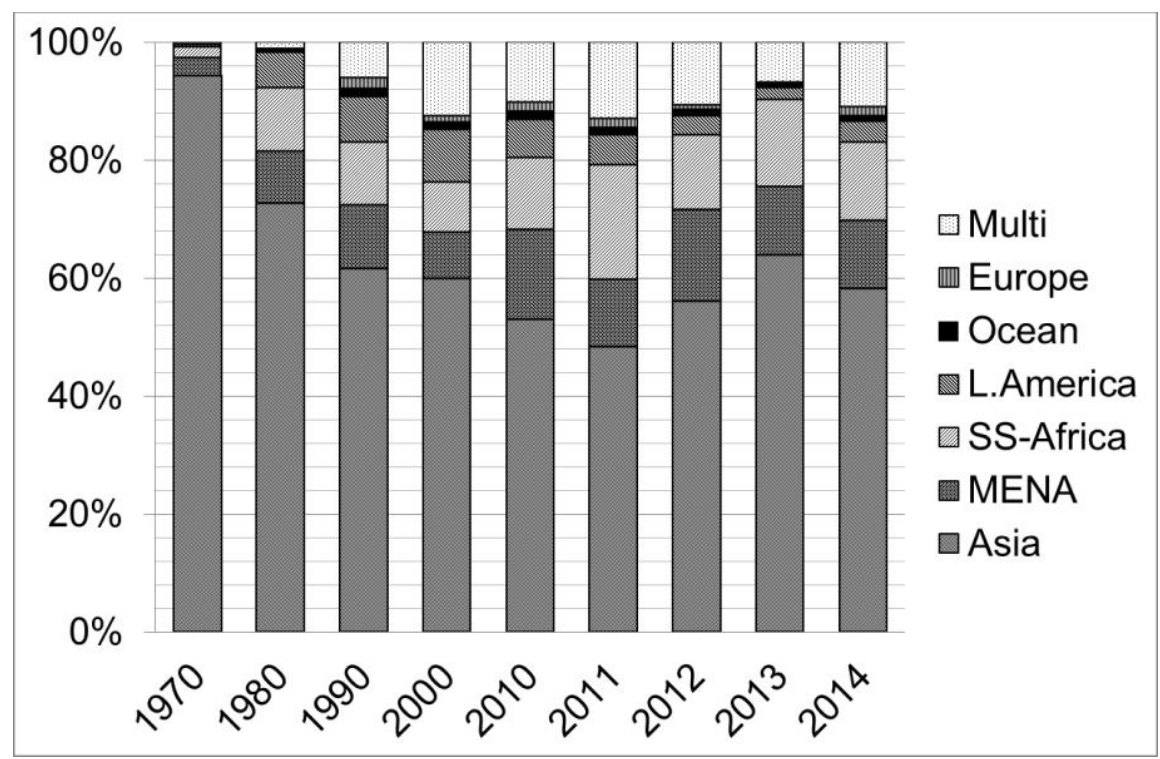

Figure 5. Share of Region in Japanese ODA

*MENA means Middle East and North Africa; SS-Africa, Sub-Sahara Africa; L. America, Latin America; Ocean, Oceania, and Multi, Multinational organizations.

Source: recreated by the author from MOFA ODA White Papers

JICA's records show that the historical top 20 destination countries for Japanese yen loans (and the amount in JPY billion in parenthesis) for the period from 1961 to 2015 were Indonesia (4 934); India (4 593); China (3 382); the Philippines (2 698); Vietnam (2 484); Thailand (2 222); Bangladesh (1 198); Sri Lanka (1 010); Malaysia (949); Myanmar (885); Pakistan (812); Turkey (699); Iraq (605); South Korea (599); Egypt (597); Peru (434); Brazil (423); Kenya (376); Morocco (306); and Tunisia (305). Apparently top 11 of them are all Asian countries and only one African country, Kenya, appears here as the 18th recipient of Japan's yen loans.

\subsubsection{Recent Trends in Yen Loans}

As shown above, Japanese FDI in Asia has been guided by the vanguard effect of Japanese ODA, and JETRO's survey revealed a number of Japanese companies hoped for the Japanese government's assistance in some sort. It is a fact that yen loan is one of the major forms of ODA. Hence, it is increasingly important for those who wish to attract Japanese FDI to also win Japan's yen loans. According to JICA, the total amount of yen loans issued during the period between 2011 and 2015 was approximately JPY 6438.6 billion, and the top 20 recipient countries of Japanese yen loan (and amount in JPY billion in parentheses) were India (1 426.0); Vietnam (890.2); Philippines (494.0); Bangladesh (480.6); Myanmar (475.0); Indonesia (248.6); Iraq (239.6); Sri Lanka (209.7); Ukraine (155.2); Uzbekistan (151.7); Kenya (109.5); Turkey (105.0); Egypt (92.7); Tunisia (80.1); Cambodia (75.3); Mozambique (61.2); Morocco (59.5); Mongolia (50.1); Brazil (50.0); and Jordan (48.2). It is easily noticed from this list that a large part of yen loans went to Asian countries, although some countries of economies of transition are also gaining favor for yen loans. Within Africa, Kenya remains the top recipient of Japan's yen loans, followed by Egypt.

\subsubsection{Recent Yen Loan for African Countries}

African countries have been given special attention from the Japanese government -in terms of ODA - because of the TICAD process. During the period between 2011 and 2015, for instance, African countries granted with yen loans (total amount in JPY billion) were Kenya (109.5); Mozambique (61.2); Tanzania (24.4); Uganda (20.0); Angola 
(23.6); Cape Verde (21.5); Botswana (8.7); Nigeria (8.3); Cameroon (6.3); and Zambia (2.9). Nevertheless, the general tendency that the majority of Japan's yen loans go to Asia has not changed.

Table 3 compares regional shares in Japanese yen loans before-and-after 2000. For the period between 2001 and 2014, in terms of yen loans, the combined share for Sub-Saharan countries was less than 5\% of funding, while Asia got $80.6 \%$ in this same time period. Despite the TICAD efforts, Japan's focus on Asia for yen loans actually shows to be slightly strengthened and paradoxically the share of Sub-Sahara Africa loans became smaller.

Table 3. Regions' share in Japanese yen loan before and after 2000 (in USD million)

\begin{tabular}{ccrrrrrr}
\hline Period & Asia & MENA & $\begin{array}{c}\text { Sub-Sahara } \\
\text { Africa }\end{array}$ & $\begin{array}{c}\text { Latin } \\
\text { America }\end{array}$ & Oceania & Europe & Total \\
\hline $1969-2000$ & 84340.1 & 11032.8 & 4913.4 & 7068.1 & 478.0 & 299.0 & 108131.3 \\
(share) & $(78.0 \%)$ & $(10.2 \%)$ & $(4.5 \%)$ & $(6.5 \%)$ & $(0.4 \%)$ & $(0.3 \%)$ & $(100 \%)$ \\
\hline $2001-2014$ & 78329.2 & 9080.1 & 3227.4 & 4713.6 & 187.6 & 1635.7 & 97173.6 \\
(share) & $(80.6 \%)$ & $(9.3 \%)$ & $(3.3 \%)$ & $(4.9 \%)$ & $(0.2 \%)$ & $(1.7 \%)$ & $(100 \%)$ \\
\hline
\end{tabular}

Source; MOFA, http://www.mofa.go.jp/policy/oda/page23_000818.htm

\section{Comments for African Countries}

Thus far, this paper demonstrated such importance of Japanese yen loans for a country that it is a prerequisite to mass FDI from Japan if the country wishes to boost Japanese FDI. The current climate is ripe for African countries to attract more Japanese FDI due to the TICAD process. Moreover, this paper lists two additional points regarding Japan's yen loans before conclusion.

\subsection{OECD Rules and Japan's Policies on ODA and Yen Loans}

Japan's yen loans are implemented within the OECD-DAC framework; therefore, Japan cannot provide yen loans in violation of the OECD-DAC rules such as rules on loan qualification status determined by per capita GDP and the those on eligibility for tied or untied aid. For the sake of promoting FDI from Japan, countries with low to lower-middle income economies that qualify for tied yen loans have an advantage whereas upper middle-income countries are ineligible for tied loans. However, some exceptional cases exist especially when a project needs to be implemented with Japan's advanced technologies; with a high anticipation that Japanese companies can win the project, the Japanese government finds it beneficial to provide financial support for such a project. For example, in spite of its upper-middle income status, Turkey won Japan's yen loans in 2013, for their infrastructure development project which needed Japan's strong anti-seismic technologies; Japanese companies were naturally the strongest contenders in the tender processes for such projects.

In addition, one needs keep in mind that the Japanese government has its own priority fields as listed below (JICA, 2015).

(i) Global Environmental Problems and Climate Change,

(ii) Health and Medical Care and Services,

(iii) Disaster Prevention and Reduction,

(iv) Human Resource Development.

While listing the four focus subjects, Japan also specifies the broad types of infrastructure as its preferred categories including bridge, tunnel, principal roads, ports, airports, urban traffic systems, IT and communication, power generators and power distribution systems, oil and gas transport and storage facilities, urban flood control, environment, medical devices, disaster management and other subjects in which Japan is technically advanced.

\subsection{Japan's Infrastructure Export}

The Japanese government decided to take the center role in promoting infrastructure export from Japan, and in 2014 to facilitate such efforts, created an organization called the Japan Overseas Infrastructure Investment Corporation for Transport and Urban Development (JOIN). JOIN aims to achieve JPY 30 trillion (about USD 300 billion) in winning 
orders for infrastructure projects by 2020 . JOIN supports Japanese companies' ability to participate in the global infrastructure export and in expands potential business opportunities.

Infrastructure export has been actively supported by Japan's yen loans - as seen in JOIN's homepage (JOIN, 2017) as "the Mixed-use Urban Development Project in the suburb of Jakarta (logistic support)" in Indonesia (up to JPY 3.4 billion); "the Urban Development Project -Landmark Project- in Central Yangon" in Myanmar (USD 20 million); "Urban Passenger Railway Transportation Project in Brazil" in Brazil (JPY 5.6 billion); "the Texas High-Speed Railway Project" in USA (USD 40 million); and "the Management and Operation of Thi Vai International Port's Terminal Business in Vietnam as its First Project" in Vietnam (JPY 1.2 billion of capital and debt guarantee of JPY 850 million); which add up to about JPY 17 billion assuming the conversion rate be JPY100/USD. JOIN's goal alone implies that, for Japan, there is a large room for more infrastructure projects to support before the end of 2020. The Cabinet Office of Japan also stated that the infrastructure projects supported by JOIN are also subject to yen loans (Cabinet Office, 2016b). As JOIN prioritizes urban development projects, this infrastructure investment scheme is highly relevant to African countries with rapidly expanding urban areas and infrastructure development projects.

\section{Conclusion}

The result of this paper clearly shows a positive and substantial effect of yen loans on the size of FDI from Japan. Examining the relationship between ODA and FDI from Japan to other Asian countries, it is undeniable that Japanese yen loans have paved the road for Japanese FDI. The econometric model used in this paper indicated that yen loans attract three times large FDI from Japan as yen loans themselves for the case of Asia. Such an effect of ODA on FDI was recognized and documented as the "vanguard effect." Preceding studies found that the vanguard effect is especially significant between Japanese ODA and FDI and the result of this paper supports the preceding finding.

The private investment focus of the Tokyo International Conference on African Development has been gradually strengthened and during the sixth meeting (TICAD VI) in 2016 in Kenya, Japanese Prime Minister Mr. Abe promised to achieve USD 30 billion investment into the African continent during the period from August 2016 to the end of 2019; one third of this amount will be funded through ODA and the rest as private investment. In accordance with the finding of this paper, this will be possible if Africa is successful in implementing a sufficient amount of Japanese ODA projects in the manners that promote FDI from Japan. For this purpose, yen loans are the most effective mean of ODA; assuming the Asian case also applies to Africa, if Africa wins a total of USD 7.5 billion ( a quarter of pledged USD 30 billion) in the form of yen loan, it can induce USD 22.5 billion of private investment from Japan.

African nations need to win yen loans from Japan if they wish to attract more FDI from Japan. When creating projects supported by yen loan, it is crucial to take into account the OECD-DAC rules in order for tied aid projects to more efficiently facilitate involvement of Japanese companies. Also, it is beneficial to keep in mind that Japan has its own priorities for yen loans: Global Environmental Problems and Climate Change; Health/Medical Care and Services; Disaster Prevention and Reduction; and lastly Human Resource Development. In addition, Japan promotes a national effort to export high-quality infrastructure; for example, the projects facilitated through the Japan Overseas Infrastructure Investment Corporation for Transport and Urban Development (JOIN) can benefit African countries.

\section{Acknowledgement}

I thank Ms. Katie Conlon, a PhD student of the Portland State University, for her kind assistance and valuable comments.

\section{References}

Blaise, S. (2009). Japanese aid as a prerequisite for FDI: the case of southeast Asian countries, Asia Pacific Economic Papers, No. 385.

Blonigen, A, B., \& Piger, J. (2011). Determinants of Foreign Direct Investment. Working Paper 16704, NBER, Cambridge, USA. Retrieved from http://www.nber.org/papers/w16704

Cabinet Office, Government of Japan. (2016a). Economic-Financial Report (in Japanese). Retrieved from http://www5.cao.go.jp/j-j/wp/wp-je13/h02_02.html

Cabinet Office, Government of Japan. (2016b). Infrastructure Export Strategy (in Japanese). Retrieved from http://www.kantei.go.jp/jp/singi/keikyou/dai24/kettei.pdf 
Cevis, I., \& Camurdan, B. (2007). The Economic Determinants of Foreign Direct Investment in Developing Countries and Transition Economies. The Pakistan Development Review, 46(3), 285-299.

Chen, X. M. (2009). Regional Economic Integration and Geographic Concentration of Multinational Firms. European Economic Review, 53, 355-375.

Harms, P., \& Lutz, M. (2006, July). Aid governance and private foreign investment: some puzzling findings for the 1990s'. The Economic Journal, 116, 773-790.

Hattai, R., \& Rajan, R. S. (2008). Trends and Drivers of Bilateral FDI Flows in Developing Asia: Extent of de Facto Integration, World Bank.

Japan External Trade Organization (JETRO). (2015). JETRO's FY2015 Survey on Business Conditions of $\begin{array}{lllll}\text { Japanese-Affiliated } & \text { Firms } & \text { in } & \text { Africa. } & \text { Retrieved }\end{array}$ https://www.jetro.go.jp/en/news/releases/2016/6c3a8a624babc59e.html

Japan External Trade Organization (JETRO). (2016). JETRO Survey on Business Conditions of Japanese Companies in Africa. Retrieved from https://www.jetro.go.jp/en/news/releases/2017/a095feb5e1aff8b4.html

Japan External Trade Organization (JETRO). (2017). Database. Retrieved from https://www.jetro.go.jp/world/japan/stats/fdi.html, 17 March 2017

Japan International Cooperation Agency (JICA). Database. Retrieved from https://www.jica.go.jp/regions/downloads/ xml.html

Japan International Cooperation Agency (JICA) (2015). Major Terms and Conditions of the Japanee ODA Loans, 2015.

Retrieved

from https://www.jica.go.jp/english/our_work/types_of_assistance/oda_loans/standard/2015_2.html

Japan Overseas Infrastructure Investment Corporation for Transport and Urban Development (JOIN). (2017). Investment. Retrieved from http://www.join-future.co.jp/english/our-mission/ investments.html

Kimura, H., \& Todo, Y. (2009). Is Foreign Aid a Vanguard of Foreign Direct Investment? A Gravity-Equation Approach. World Development, 38(4), 482-497.

Ministry of Foreign Affairs, Japan (MOFA). (2014). ODA White Paper 2014. Retrieved from http://www.mofa.go.jp/policy/oda/page23_000818.html

Ministry of Foreign Affairs, Japan (MOFA). (2016). Address by Prime Minister Shinzo Abe at the Opening Session of the Sixth Tokyo International Conference on African Development (TICAD VI) (Saturday, August 27, 2016). Retrieved from http://www.mofa.go.jp/afr/af2/page4e_000496.html

Ministry of Foreign Affairs, Japan (MOFA). Japanese ODA Database. Retrieved from http://www3.mofa.go.jp/mofaj/gaiko/oda/shiryo/jisseki/kuni/index.php

MUFJ Research Consulting. (2016). Mid-term Outlook for Japanese Economy (2015 - 2030) (in Japanese). Retrieved from http://www.murc.jp/thinktank/economy/economy_prospect/midium /medium_1603.pdf

Quazi, R. M., Williams, M. F., Baldwin, R., Vesey, J., \& Ballentine, W. E. (2014). Impact of Foreign Aid on Foreign Direct Investment in South Asia and East Asia. International Business Research, 7(12), 44-52.

Selaya, P., \& Sunesen, E. R. (2008). Does Foreign Aid Increase Foreign Direct Investment?. Discussion Papers No. 08-04, Department of Economics, University of Copenhagen.

The Medium and Small Business Research Institute (2011). Overseas Expantion of Medium and Small Enterprises, A Study on Globalized Companies (in Japanese). Retrieved from https://www.chukiken.or.jp/study/report/125.pdf

World Bank, database $\quad$ Retrieved from http://siteresources.worldbank.org/DATASTATISTICS/Resources/OGHIST.xls

\section{Note}

Note 1. Data were collected from the internet homepages of JICA for ODA related data and from JETRO for FDI related data as follows. 